International Journal of Agriculture, Environment and Bioresearch

Vol. 06, No. 04; 2021

ISSN: $2456-8643$

\title{
DETERMINATION OF CLIMATIC ZONES OF INFLUENCE IN THE YAQUI AND MAYO VALLEYS, MEXICO
}

\author{
TORRES-CRUZ Maria Monserrat ${ }^{1}$, CASTRO-QUIROA Luis Adrian ${ }^{1}$, FUENTES-DÁVILA Guillermo ${ }^{2}$ and \\ FELIX-VALENCIA Pedro ${ }^{2}$ \\ ${ }^{1}$ INSTITUTO TECNOLÓGICO DE SONORA,5 de Febrero 818, Col. Centro, Cd Obregón, Sonora, México CP \\ 85000 \\ ${ }^{2}$ INIFAP, CAMPO EXPERIMENTAL NORMAN E. BORLAUG ,Apdo. Postal155, km 12 Norman E. Borlaug, \\ entre 800 y 900, Valle del Yaqui, Cd. Obregón, Sonora, México CP85000
}

https://doi.org/10.35410/IJAEB.2021.5650

\begin{abstract}
Climate change has been affecting negatively agriculture in various regions of the world. In the valleys of southern Sonora, Mexico, there have been changes in climate like frost and heat waves, which have aggravated the presence and incidence of pests and diseases on different crops. This has also affected crops' phenological development, with the consequent impact on yield and quality. Through the technological development of data collection systems of climatological variables through weather stations, it has been possible to generate large amounts of climate data in the Yaqui and Mayo valleys. Advances in computing systems have made it possible to manage, analyze, and interpret climate data. This work aims at applyinga datum mining technique to create zones of climate influence by using the temperature and relative humidity of 23 weather stations located in the Yaqui and Mayo valleys during the years 2015 to 2019. Inclusion criteria for the weather stations were data consistency and their representative location within the region. The data mining technique used was clustering under the principal components method, by which four zones of climate influence in the region were identified. The first zone was located in the central part of the region; the second zone in the western part of the Yaqui Valley; the third zone consists of three of the four stations located in the mountainous zone of the region; and the fourth zone comprises stations located near the coastal area.
\end{abstract}

Keywords: Temperature, relative humidity, technological innovation, data mining, cluster analysis, Yaqui Valley, Mayo Valley, Mexico.

\section{INTRODUCTION}

The Yaqui and Mayo Valleys in southern Sonora, Mexico, are regions in which climatic conditions are different, as it has been shown by the survey carried out during the year 1991, when the incidence of the disease known as karnal bunt of wheat was greater in the Mayo Valley[1]. The same has happened with appearance and development of stripe or yellow rust[2], leaf rust[3] and spot blotch of wheat in the two valleys according to the reports generated by the local boards of plant health.The Yaqui Valley is one of the main regions of agricultural production in northwest Mexico $\left(27^{\circ} \mathrm{N}, 110^{\circ} \mathrm{W}\right)$, it covers the area between the Sierra Madre to 
Vol. 06, No. 04; 2021

ISSN: $2456-8643$

the East and the California Gulf to the West. The climate is semiarid, with variable precipitation rates with an annual average of $317 \mathrm{~mm}$ and a temperature average of $21^{\circ} \mathrm{C}$ during the crop season fall-winter and $30^{\circ} \mathrm{C}$ for the crop season spring-summer[4].Such valley has a territorial extension of 2,117,220 ha which represents $11.4 \%$ of the total area of the state of Sonora and 1\% of Mexico [5]. The valley is fed by and aquifer with an area of $1,966 \mathrm{~km} 2$, where the irrigation district 041 Rio Yaqui has developed, in the lower part of the basin which is the largest and most important of Sonora[6].Similarly, the Mayo Valley is located in the extreme south of Sonora, with an aquifer area of 1,071 km2and is part of the same coastal plane where the Yaqui Valley is located the to the north and northwest. The irrigation district 038 Rio Mayo has developed from the lower part of the basin [7].The climate of the region is defined as very warm and desert climate with an annual temperature average of 23 a $27^{\circ} \mathrm{C}$, with a maximum range of 43 to $48^{\circ} \mathrm{C}$ duringJune, July and August, and a minimum range of 3.5 to $4^{\circ} \mathrm{C}$ in Decembre and January. The annual precipitation average range is from 200 to $400 \mathrm{~mm}$ concentrated during July to September with 70\%[8].The most important crops in southern Sonora are wheat, cotton, soybean, sawflower, and maize.Crop pattern has been modified with increasing are of vegetables due to economic problems and drought; however, the most important crop continues to be wheat with an area sown greater than 150,000 ha, and a yield average of $6 \mathrm{t} / \mathrm{ha}$ [9].The wheat season (November-April) is particularly dry and farmers apply an average of 4-5 irrigations during the crop season.Climate consists of weather factor which determine the activity in the primary productive sectors, considering the agricultural sector, forestry, and livestock. The availability of raw material and food coming from these sectors make in great extent, the production models within the industry which is known as production seasonality[10]. The influence of climate in a crop is highly relevant, since it does not only depend on the climatic characteristics of the locality, but also to a great extent upon the conditions over which production takes place[11]. Regarding the wheat crop, temperature is the weather variable with the greatest impact on productivity[12], but it also might cause adverse effects such as less productivity triggered by frosts and heat waves[13]. Therefore, wheat in the state of Sonora is the crop that shows a favorable expression in grain yield, when the occurrence of cold hours is well distributed during plant growth. Diseases and pests of crops are highly relevant for production, since they can affect the crops and cause yield losses, such losses reach an annual average of 12-13\% [14].Relative humidity is fundamental in all active stages of phytopathogens; the temperature-humidity interaction establishes the methodology for the forecast of important diseases[15].Currently, there is an automated weather station network in the state of Sonora, that serve as a tool for the decision-making in the agricultural sector. Based on the data and its analysis, it is posible to offer technical recommendations towards the reduction of the impact of adverse conditions[11]. There are 113 weather stations which belong to the automated weather station network of Sonora (REMAS), which has the objective to generate, store, process, and disseminate weather data in the state. Such weather stations constantly collect data with a frequency of 10 minutes, and provide integrated data by the hour and day, so that the air temperature (minimum and maximum)can be evaluated, as well as the relative humidity, precipitation, solar radiation, speed and wind direction, barometric pressure, and evapotranspiration. Several studies that have been carried out using the data provided by the weather stations[1], [14], [16], have demonstrated that the fluctuacion of temperature and humidity between sites in the Yaqui and Mayo Valleys causes differences in crop yields, and influence the presence and incidence of pests and diseases in 
Vol. 06, No. 04; 2021

ISSN: $2456-8643$

different areas of the valleys.To describe and predict weather behaviour, statistical tools and techniques have been used recurrently and systematically, such as the arithmetic mean, simple determination, standard deviation, hypothesis testing. However, these are limited in order to have a good analysis and interpretation when compared with more sophisticated techniques such as data mining[17]. Since the volumen of climatic data increases as the period of time gets longer for analysis, consequently, the dificulty to handle and interpret such volumen of data, also increases.There is also the need to have specialized personnel to carry out this type of analysis. The different techniques for data mining applied to the information from the weather station network, allow to obtain knowledge and it is very useful for decision-making, such as the generation of tendency rules based on precipitation and temperature, and also for calculation of damage severity in areas affected by fire, flooding or any other climatological event[18].Cluster analysis is one of the statistical procedures used for group segmentation, defining groups as different as possible in function of the data without previous specification[19]. Therefore, zoning orsecctioning the climate has evolved, since there is analysis with statistical facts so that the conformation of clases or groups would be more objective, and additionaly help to the organization of observations with the reduction of the quantity of data to be analyzed[20]. The objective of this work was to carry out a specific analysis of temperature and relative humidity for each weather station of REMASlocated in the agricultural areas of the Yaqui and Mayo Valleys, in order to determine zones with related climatic conditions, where prediction models for production and phytosanitary alerts could help the farmers with a more efficient planning, less contamination of the environment, and economically profitable with regard to the agronomic management of their crops.

\section{ANTECEDENTS}

In other regions, artificial neural networks have been used, as well as decision-making trees, in order to predict the maximum temperature, precipitation, evaporation, and wind speed[21]. Also, plant traits (stem diameter, height and plant weight, pre and post flowering, spike diameter, plant weight in maturity) have been identified which have incidence upon final yield of maize, such as grain weight, and number of grains per plant[22].Furthermore, neuronal networks have also been used for evaluation of the area sown (wheat and potato) in function of time and precipitation, and the production in function of time, precipitation, and area sown[23].Studies on the climate have used a variety of data to define the types of climate, and to deliniate zones with similar characteristics, such the case of Turkey were current climatic zones were redifined through the data mining technique with cluster analysis, and as a result, not only differences in climate were determined, but also social and economic variables[24]. In the year 2015 the geographic information system and the process of analytical hierarchy were used for zoning in the Golestan province in northern Iran, basedon factors such as average temperature, minimum and maximum, slopes, soil characteristics such as organic matter, $\mathrm{pH}$, texture, macro and micronutrients, with the objective to determine the best areas adapted for wheat cultivation[25].In Mexico,multivariate methods have been used to identify areas with similar climatic conditions and to define climatic indexes for Mexico City[26]. Other studies carried out with the help of application of computer models based on inductive learning and process of quality and homogeneity, was the obtention of tendency rules for the predictionprecipitation in the state of Morelos, Mexico[18].The climatic regionalization of the state of Michoacan, Mexico, was also 
accomplished by three different grouping techniques: two-stage sampling (hierarchy), mean-K (partitional) and Kohonen network, being the variables of influence: precipitation, observed temperature, maximum and minimum temperature; this because these variables showed continuous data in a span of at least 20 years[27].

\section{METHOD}

\subsection{MATERIALS}

To carry out this work, 23 of the 34 weather stations from REMAS which cover the Yaqui and Mayo Valleys, were taken into consideration (Table 1). The data set contains a total of 89,400records captured between 2015 and 2019 (inclusive). These records are generated by sensors that measure several climatic variables, consideringthe variables air temperature(specific heat grade of the air) and relative humidity (relationship between the amount of water vapor that an air mass has and the maximum that it could have),since they have a very important role in relation the appropriate crop development[28], and to the development of pests and diseases[29].

Table1.Selected weather stations for the analysis

\begin{tabular}{|c|c|c|c|}
\hline COD. & NAME & LATITUDE & LONGITUDE \\
\hline Y01 & $\begin{array}{c}\text { BLOCK 1936 } \\
\text { SIBOLIBAMPO }\end{array}$ & 27.17639 & -109.66167 \\
\hline Y02 & $\begin{array}{c}\text { BLOCK 2328 AGUA } \\
\text { BLANCA }\end{array}$ & 27.10628 & -109.74821 \\
\hline Y03 & BLOCK 1922 & 27.17227 & -109.80183 \\
\hline Y04 & $\begin{array}{c}\text { BLOCK 2010 (SANTA } \\
\text { MARIA) }\end{array}$ & 27.14312 & -109.90211 \\
\hline Y05 & $\begin{array}{c}\text { BLOCK 1418 (SAN } \\
\text { VICENTE) }\end{array}$ & 27.28076 & -109.84066 \\
\hline Y06 & BLOCK 1703 LOTE 6 & 27.22619 & -110.04359 \\
\hline Y07 & BLOCK 910 (CIANO) & 27.36959 & -109.92892 \\
\hline Y08 & BLOCK 1423 LOTE 1 & 27.28106 & -110.25909 \\
\hline Y09 & $\begin{array}{c}\text { BLOCK 1213 } \\
\text { ATOTONILCO }\end{array}$ & 27.3175 & -110.15722 \\
\hline Y10 & BLOCK 609 (CAWE) & 27.41409 & -110.0989 \\
\hline Y11 & BLOCK 731 LOTE 20 & 27.4034 & -110.3426 \\
\hline Y12 & $\begin{array}{c}\text { BLOCK 111 SAN JOSE DE } \\
\text { BACUM }\end{array}$ & 27.51458 & -110.11925 \\
\hline Y13 & ESTACIÓN CORRAL & 27.61581 & -109.92711 \\
\hline Y14 & POTAM & 27.63122 & -110.40925 \\
\hline M01 & CHIHUAHUITA & 27.10632 & -109.47862 \\
\hline M02 & TESIA & 27.12977 & -109.40153 \\
\hline M03 & SEMAY & 27.01119 & -109.50101 \\
\hline
\end{tabular}




\begin{tabular}{|c|c|c|c|}
\hline M04 & $\begin{array}{c}\text { NAVOBAXIA (LAS } \\
\text { PIOCHAS) }\end{array}$ & 26.83591 & -109.68455 \\
\hline M05 & $\begin{array}{c}\text { HUATABAMPO (LOS } \\
\text { CUATES) }\end{array}$ & 26.82294 & -109.59879 \\
\hline M06 & LA REGLA & 26.80951 & -109.52631 \\
\hline M07 & $\begin{array}{c}\text { TRES CARLOS (EL } \\
\text { GIRASOL) }\end{array}$ & 26.91342 & -109.49548 \\
\hline M08 & CAMPETAMAYA & 26.96589 & -109.42393 \\
\hline M09 & SAHUARAL DE OTERO & 26.89783 & -109.74847 \\
\hline
\end{tabular}

Weather stations starting with $\mathrm{Y}$ belong to the Yaqui Valley,and those with $\mathrm{M}$ to the Mayo Valley.

The methodology Cross Industry Standard Process for Data Mining (CRISP-DM) [30]was used focused on treating the weather data and the implementation of the data mining techniques for classification. The steps were the following:

\subsection{Procedure}

\subsubsection{Data understanding}

Data were obtained from the weather stations located in the Yaqui and Mayo Valleys within the REMAS platform. Average temperature, relative humidity, maximum and minimum temperature were selected from each month during the years 2015 to 2019 with the frequency of an hour.

\subsubsection{Data preparation}

Data concentration of the different variables from the each weather station was performed, with the objective of selecting weather stations based on the quality of the data, using availability dimensions, completeness and integrity;besides the representation of the agricultural area in southern Sonora.The main inclusion criterium for the records from the weather stations was consistency of data, that is, the percentage of missing data were less $\tan 20 \%$ (nine stations were in this category). The analysis was performed with SAS Studio. Weather stations in Blocks 2732, 720, and Pueblo Mayo were also discarded since geographically, they are not representative of the agricultural area in southern Sonora.

\subsubsection{Modeling}

In this stage, the data mining technique called cluster analysis was usedthrough main components (MC) in SAS Studio. Main components is an objective statistical technique for classification which tends to gather a group of objects in groups or clusters, whose members are more similar between them than with other objects from different groups [20]. The purpose is to reduce a dimensional space pto a new dimensiond, wheredis much smaller thanp, but at the same time it represents as much as possible data variation[31]. That is, data are transformed into a new set of coordinates or variables which are a lineal combination of the original variables.In SAS 
Studio (PROC VARCLUS), each cluster component is calculated from a set of variables which is different to all other cluster components. The first main component of a set might be correlated with the first main component from another set. In the analysis of main components, the covariance matrix is analyzed where variables with greater variations are more important in the analysis, and by a dendrogram (diagram of hierarchy tree groups) the results are shown, with the hierarchy of clusters as they are being built[32].

\subsubsection{Variables evaluated}

Each cluster was analyzed in order to describe the microclimate through the average air temperature, maximum and minimum temperature and average relative humidity of each cluster identified.

\section{RESULTS}

After the evaluation of all the variables in a single cluster, the total explained variation was 22.62; therefore, the explained variance by the variables from a group is similar to the explained variance by a factor in the common factorial analysis, which unlike this, it only includes contributions by the variables in the group instead of all the variables, which represents to a great extent part of the variability of the data as possible[32].Then, the cluster was divided into two groups. Each variable was established to the component which has the highest grade of relationship among variables, so that 13 stations made the first group and 10 in the second group (Table 2).

Table2. Summary for two clusters

\begin{tabular}{|l|c|c|}
\hline Cluster & $\mathbf{1}$ & $\mathbf{2}$ \\
\hline Members & 13 & 10 \\
\hline Explained variation & 12.83 & 9.85 \\
\hline Explained proportion & 0.98 & 0.98 \\
\hline Second autovalue & 0.04 & 0.04 \\
\hline
\end{tabular}

To a variance proportion of 0.98 , cluster 1 it is divided into two subgroups because it has the second hightest autovalue; group 2 is divided into two because the proportion variance is 0.98 the highest of the three groups, making a total of four groups[32]. The way in which the weather stations are making the clusters is shown as a dendrogram in Figure 1. 


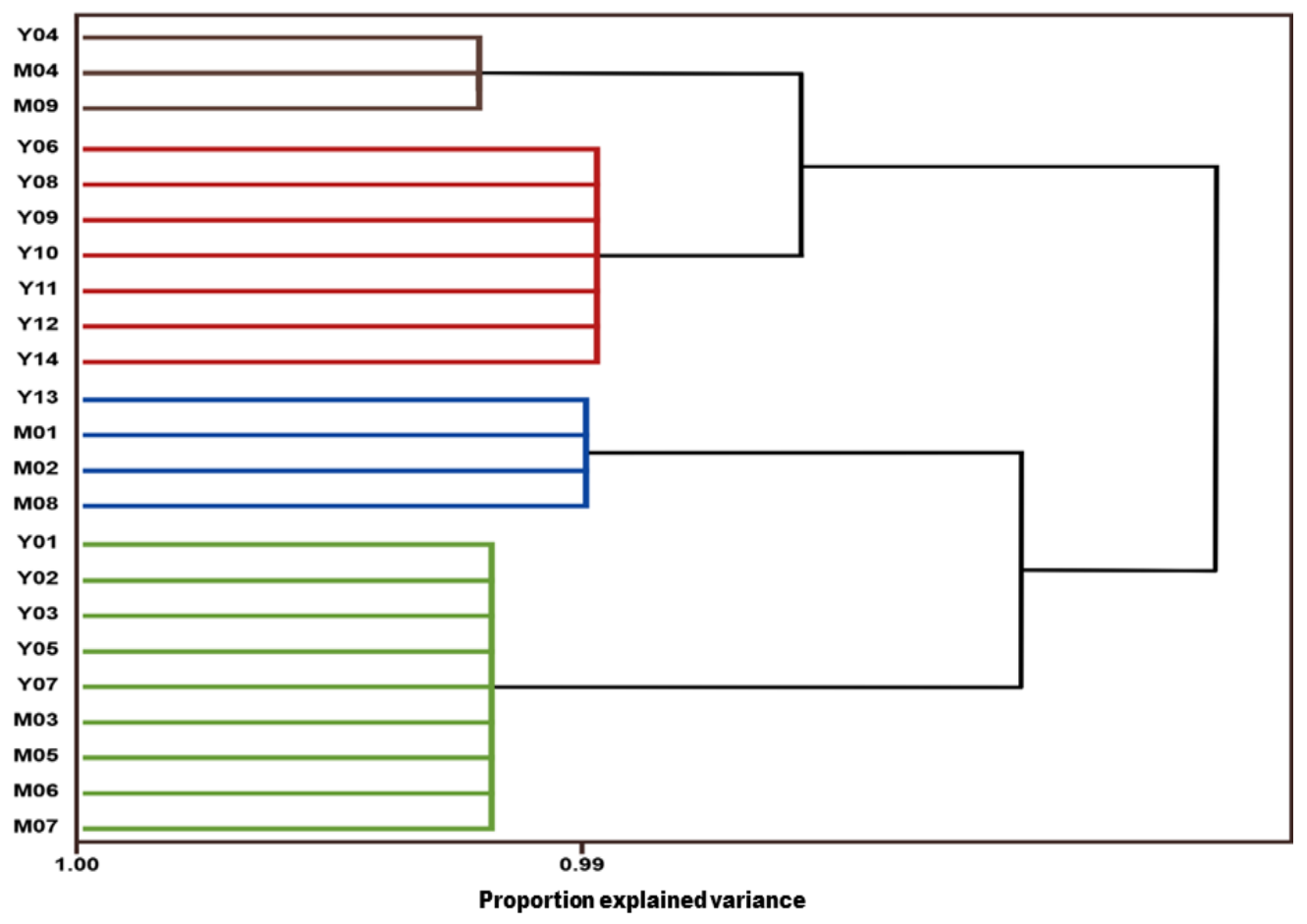

Figure 1. Dendrogram from the analysis of weather stations.

Table 3 shows the name of the weather stations belonging to each group, the explained variation, explained proportion, and the final proportion which represents the total explained variation divided by the sum of the group variation, generating a result of 0.99 . This value indicates approximately that $99 \%$ of the data are used to obtain the information, and explains the four clusters found.Based on the information from Table 3, zone 1 is characterized by an average temperature of $23.3^{\circ} \mathrm{Cand}$ the lowest relative humidity with $59.9 \%$; in zone 2, the average temperature is $23.2^{\circ} \mathrm{C}$ and the relative humidity $68.5 \%$; in zone 3 occurs the highest and lowest average temperature with $37.7^{\circ} \mathrm{C}$ and $10.3^{\circ} \mathrm{C}$, respectively; while zone 4 is characterized by the lowest average temperature and the highest relative humidity with $22.9^{\circ} \mathrm{Cand} 72.8 \%$, respectively.

Therefore, in relation to the division of clusters (Table 3), cluster 1 (blue circles in Figure 2) comprise stations located in the central area of both valleys; cluster 2 (pink circles) is located in the western part of the Yaqui Valley;cluster 3 (yellow circles) consists of three out of four stations located in the mountanais area of the region; and cluster 4 (red circles) comprises stations located in the coastal area (Figure 2).In relation to the global average of each variable and the average obtained in each climatic zone, in general, the four zones were closet to the average temperature of the five years which was $23.21^{\circ} \mathrm{C}$. The maximum global temperature was $36.38^{\circ} \mathrm{C}$, in which zone 3 had $1.4^{\circ} \mathrm{Cabove}$ the global average, while zone 4 was lower than the global average by $1.07^{\circ} \mathrm{C}$. It should be considered that it is about climatic conditions and that a 
single temperature grade impacts the agricultural sector, either in a positive or negative way to crops.

Table3. Characteristics that define the four clusters (the first row represents the clusters).

\begin{tabular}{|c|c|c|c|c|}
\hline & 1 & 2 & 3 & 4 \\
\hline \multirow{4}{*}{$\begin{array}{c}\text { CODE FOR WEATHER } \\
\text { STATIONS }\end{array}$} & Y01 & Y06 & Y13 & Y04 \\
\cline { 2 - 5 } & Y02 & Y08 & M01 & M04 \\
\cline { 2 - 5 } & Y03 & Y09 & M02 & M09 \\
\cline { 2 - 5 } & Y05 & Y10 & M08 & - \\
\cline { 2 - 5 } & Y07 & Y11 & - & - \\
\cline { 2 - 5 } & M05 & Y12 & - & - \\
\cline { 2 - 5 } & M06 & - & - & - \\
\cline { 2 - 5 } & M07 & - & - & - \\
\hline EXPLAINED VARIATION & 8.91 & 6.92 & 3.95 & 2.97 \\
\hline EXPLAINED PROPORTION & 0.99 & 0.98 & 0.98 & 0.99 \\
\hline AVERAGE TEMPERATURE & 23.34 & 23.24 & 23.65 & 22.92 \\
\hline MAXIMUM TEMPERATURE & 36.24 & 36.27 & 37.73 & 35.30 \\
\hline MINIMUM TEMPERATURE & 11.17 & 11.25 & 10.33 & 10.92 \\
\hline RELATIVE HUMIDITY & 59.99 & 68.54 & 66.29 & 72.88 \\
\hline
\end{tabular}

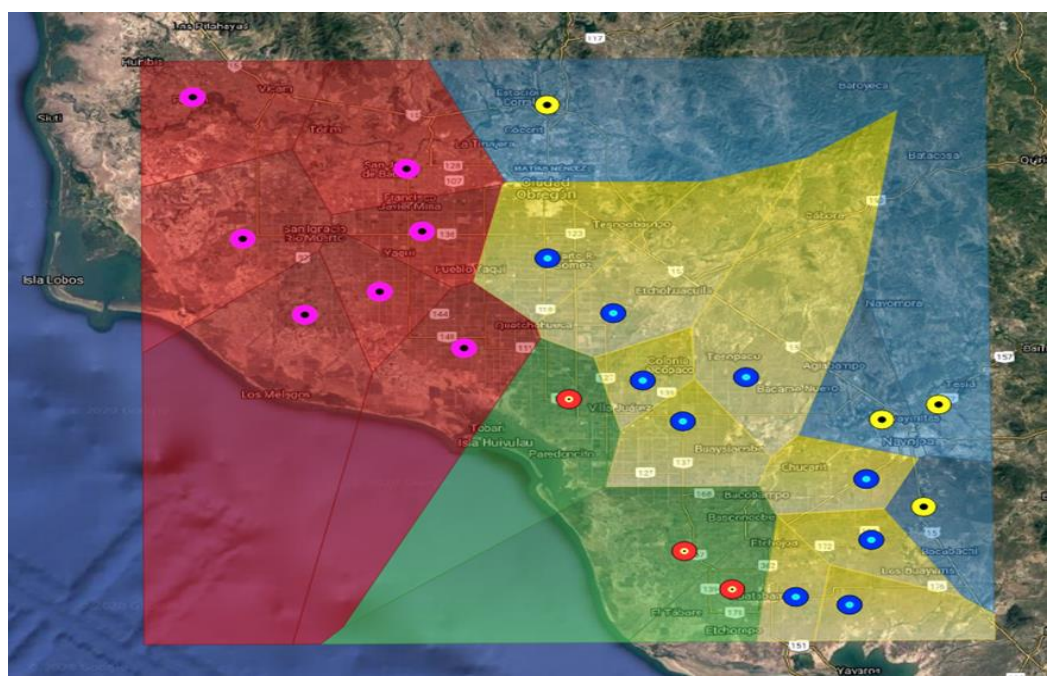

Figure 2. Clusters identified in the Yaqui and Mayo Valleys, Sonora, Mexico. 
In relation to the minimum temperature, zone 3 hadan average of $10.5^{\circ} \mathrm{Cfor}$ the five years, being lower than the global minimum temperature of $10.97^{\circ} \mathrm{C}$. On the other hand, the global average relative humidity was $68.57 \%$, and consequently zone 3 had the lowest humidity while zone 4 had the highest average humidity (Table 4).

Table 4. Average temperatures and relative humidity in the climatic zones identified in southern Sonora, Mexico, during the years 2015 to 2019.

\begin{tabular}{|c|c|c|c|c|c|c|}
\hline & & Zone 1 & Zone 2 & Zone 3 & Zone 4 & Average \\
\hline \multirow{6}{*}{  } & 2015 & 23.46 & 23.52 & 23.85 & 23.22 & 23.51 \\
\hline & 2016 & 22.88 & 23.34 & 23.65 & 22.87 & 23.19 \\
\hline & 2017 & 23.42 & 23.41 & 23.81 & 23.07 & 23.43 \\
\hline & 2018 & 23.09 & 23.16 & 23.41 & 22.91 & 23.14 \\
\hline & 2019 & 22.75 & 22.77 & 23.11 & 22.56 & 22.80 \\
\hline & Global & 23.12 & 23.24 & 23.57 & 22.93 & 23.21 \\
\hline \multirow{6}{*}{  } & 2015 & 35.86 & 35.80 & 37.42 & 35.02 & 36.03 \\
\hline & 2016 & 35.92 & 36.68 & 37.94 & 35.39 & 36.48 \\
\hline & 2017 & 36.52 & 36.74 & 38.15 & 35.48 & 36.72 \\
\hline & 2018 & 36.61 & 36.48 & 38.14 & 35.78 & 36.75 \\
\hline & 2019 & 35.83 & 35.68 & 37.23 & 34.87 & 35.90 \\
\hline & Global & 36.15 & 36.28 & 37.78 & 35.31 & 36.38 \\
\hline \multirow{6}{*}{ 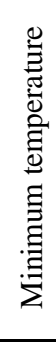 } & 2015 & 11.72 & 11.91 & 10.66 & 11.32 & 11.4 \\
\hline & 2016 & 11.29 & 11.43 & 10.89 & 10.96 & 11.14 \\
\hline & 2017 & 11.39 & 11.33 & 10.68 & 11.09 & 11.12 \\
\hline & 2018 & 10.82 & 10.89 & 9.71 & 10.67 & 10.52 \\
\hline & 2019 & 10.73 & 10.69 & 10.56 & 10.56 & 10.64 \\
\hline & Global & 11.19 & 11.25 & 10.5 & 10.92 & 10.97 \\
\hline \multirow{6}{*}{  } & 2015 & 67.26 & 67.66 & 66.49 & 71.58 & 68.25 \\
\hline & 2016 & 65.75 & 67.09 & 64.82 & 71.83 & 67.37 \\
\hline & 2017 & 66.84 & 68.78 & 65.28 & 72.99 & 68.47 \\
\hline & 2018 & 67.08 & 66.75 & 65.53 & 72.19 & 67.89 \\
\hline & 2019 & 69.33 & 70.15 & 68.24 & 75.71 & 70.86 \\
\hline & Global & 67.25 & 68.09 & 66.07 & 72.86 & 68.57 \\
\hline
\end{tabular}


Vol. 06, No. 04; 2021

ISSN: $2456-8643$

\section{DISCUSSION}

The results obtained might have several important applications. The division in climatic zones or microclimates would be very useful since in the valleys of southern Sonora, a variety of crops are sown during the agricultural seasons fall-winter and spring-summer, as well as perennial crops. Wheat, sawflower, maize, chickpeas, and potato are cultivated during the fall-winter crop season, soybean, sorghum, beans, and cotton during the spring-summer, and fruit trees like citrus, pecan, alfalfa, and asparagus are perennial[33]. Looking back at the years 2015 to 2017, average temperatures and relative humidity have been around to the global anual average, however, in2018 some months had greater frequency of high temperatures in the mountain range; also, from the end of 2018 to the beginning of 2019 there were several frosts and the minimum temperature recorded was around $-2^{\circ} \mathrm{C}$, but, major damage to the crops did not occur since the frost period was short. The year 2019 was more humid than the previous four years; therefore, these results could serve as the basis for the next years where similar conditions may occur, so that farmers could make decisions on how to handle the cropswhich they intend to cultivate.On the other hand, the identification of climatic zones may help to determine other crops subject to be cultivated in each zone, taking into account the most appropriate season for each crop, as well as the most appropriate for the best phenological development of such crops.It is important to point out that there has been studies on the influence of the climate change upon the development of pests and diseases in southern Sonora, and it has been proved that leaf rust of wheat has had favorable conditions particularly in the Mayo Valley; it is common that initiation of its presence in southern Sonora starts in this region[14]; therefore, the identification of climatic zones is highly relevant in order to generate early or preventive phytosanitary warnings in relation to the weather conditions conducive for the development of pests and diseases in diverse crops.Similarly, the división into climatic zones may be of great help to farmers by making recommendations about the agronomic management of their crops with the objective of exploiting the yield potential of their crops. That was the case about a study carried out in the northern part of the Cauca Valley in Colombia, where the region has differences and similarities between counties, which can be exploited to take competitive advantages, and by doing so, reduce the social gaps in the region[19]. In the United States the regionalization was also achieved using temperature and precipitation data with the use of hierarchy cluster analysis, which indicate that some of the subgroups within the reference groups, lackstrength and some the tests implicate large and small alterations for the data processing strategy[34].In the state of Michoacán, Mexico, a climatic regionalization was carried out by using different cluster techniques of data mining, based on the records of temperatureandprecipitation, where four regions were found with a high grade of reliability[27]. On the other hand, it is worthy to clarify that cluster analysis for identification of microclimates in the valleys of southern Sonora,has and important limititation related with the quality of the data from each of the stations. It is important to consider that 13 stations were discarded because data for the variables were not complete for the period of time analyzed.Therefore, as the number of records and the quality increase, it would be possible to refine the microclimatic zones and to achieve greater certainty about the boundaries of the identified zones through analysis using other methods such as techniques of the geographic information system (SIG), multivariat analysis, and Köppen's climatic classification. Data from REMAS are open to the public since the year 2015, so, this analysis would be greatly 
Vol. 06, No. 04; 2021

ISSN: $2456-8643$

benefited if data from previous years would be available in order to reduce the bias by atypical years.

\section{CONCLUSIONS}

Four climatic zones or microclimates were identified in the Yaqui and Mayo Valleys in southern Sonora, Mexico, based on cluster analysis of temperature and relative humidity that occurred during the years 2015 to 2019.Zone 1 comprises stations located in the central area of both valleys; zone 2 is located in the western and northern part of the Yaqui Valley;zone 3 consists of three out of four stations located in the mountain range area of the region; and zone 4 comprises stations located in the coastal area.In general, the four zones were closeto the average temperature of the five years which was $23.21^{\circ} \mathrm{C}$, but zone 3 showed the highest and lowest temperatures ranging from 37.23 to 38.15 and from 9.71 to $10.89^{\circ} \mathrm{C}$, respectively, while zone 4 showed the lowest temperatures within the highest with a range of 34.87 to $35.78^{\circ} \mathrm{C}$. The global average relative humidity was $68.57 \%$; zone 3 had the lowest humidity $(66.07 \%)$ while zone 4 had the highest $(72.86 \%)$.

\section{Acknowledgements}

This work was partially financed by the National Council of Science and Technology (CONACYT) in Mexico, with a scholarship for graduate studies No. 932355, at the Technological Institute of Sonora, Master Degree Program in Business Technology Information for the first author.

\section{REFERENCES}

[1] Lira Ibarra M. 1992. Karnal Bunt (Tilletia indica) of Wheat in the State of Sonora, México. pp. 6-9. In: Update on Karnal Bunt Research in México. Wheat Special Report No. 7. Eds. Fuentes-Davila, G., and Hettel, G.P. CIMMYT. Cd. Obregon, Sonora, Mexico. May 8-9, 1991. Pages 1-38.

[2] Fuentes-Dávila G, Torres-Cruz MM, Félix-Valencia P, Valdenebro-Esquer B, CasteloMuñoz G, and Félix-Fuentes JL. 2019. Presence of wheat stripe rust in southern Sonora during the 2018-19 crop season. Annual Wheat Newsletter 65:35-39.

[3] Singh RP, Huerta-Espino J, Pfeiffer W, and Figueroa-Lopez P. 2004. Occurrence and impact of a new leaf rust race on durum wheat in northwestern Mexico from 2001 to 2003. Plant Dis. 88(7):703-708. doi: 10.1094/PDIS.2004.88.7.703.

[4] Parra-Cota FI, Coronel-Acosta CB, Amézquita-Avilés CF, De los Santos-Villalobos S, y Escalante-Martínez DI. 2018. Diversidad metabólica de microorganismos edáficos asociados al cultivo de maíz en el Valle del Yaqui, Sonora. Revista Mexicana de Ciencias Agrícolas 9(2):431-442. doi: 10.29312/remexca.v9i2.1083.

[5] Almanza M. 2008. Las organizaciones del sector social del Valle del Yaqui: Retrocesos de política agraria. Frontera norte 20(40):135-167.

[6] Vega-Granillo EL, Cirett-Galán S, De la Parra-Velasco ML, y Zavala-Juárez R. 2011. Hidrogeología de Sonora, México. In Calmus, Thierry, ed., Panorama de la Geología de Sonora, México: Universidad Nacional Autónoma de México, Instituto de Geología, 118(8):267-298.

[7] INEGI. 1990. Estudio Hidrológico del Estado de Sonora. Accessed January 23, 2020. 
[8] Padilla Valenzuela I, Valenzuela Valenzuela RI, Armenta Castro CM, Salinas Pérez RA, y Sánchez Sánchez E. 2008. Comportamiento agronómico de genotipos de garbanzo en siembra tardía en el Valle del Mayo, Sonora, México. Revista Fitotecnia Mexicana 31(1):43-49.

[9] Cruz Medina IR. 2006. Análisis de la influencia del ENSO en el Valle del Yaqui (Sonora, México) mediante modelos de regresión dinámica y múltiple. Revista Latinoamericana de Recursos Naturales 2(2):65-80.

[10] Félix Valencia P, Leyva Corona JC, Ortiz Enríquez JE, Quintana Quiroz JG, Grageda Grageda J, y Jiménez Ortega G.2008. Comportamiento historico y tendencia del clima en la zona Agrícola y pecuaria del sur de Sonora. Expectativas ante un cambio climático. INIFAP, Centro de Investigación Regional del Noroeste, Campo Experimental Valle del Yaqui. Libro Técnico No. 4. Cd. Obregón, Sonora, México. 202 p.

[11] Medina García G, Grageda Grageda J, Ruiz Corral JA, y Báez González AD. 2009. Uso de estaciones meteorológicas en la agricultura. INIFAP, Centro de Investigación Regional Norte Centro, Campo Experimental Zacatecas. Folleto Técnico No. 50. Zacatecas, México. $19 \mathrm{p}$.

[12] Félix-Valencia P, Ortíz-Enríquez JE, Fuentes-Dávila G, Quintana-Quiróz JG, y GragedaGrageda J. 2009. Horas frío en relación al rendimiento de trigo: áreas de producción del estado de Sonora. INIFAP, Centro de Investigación Regional del Noroeste, Campo Experimental Valle del Yaqui. Folleto Técnico No. 63. Cd. Obregón, Sonora, México. 40 p.

[13] Félix-Valencia P, Ortiz-Enríquez JE, Cabrera-Carbajal F, Chávez-Villalba G, FuentesDávila G, y Figueroa-López P. 2012. Daños a la producción de trigo causado por heladas en el sur de Sonora. Diagnóstico del ciclo de trigo oi-2010-2011. INIFAP, Centro de Investigación Regional del Noroeste, Campo Experimental Norman E. Borlaug. Folleto Técnico No. 87. Cd. Obregón, Sonora, México. 70 p.

[14] Grageda Grageda J, Ruiz Corral JA, Jiménez Lagunes A, y Fu Castillo AA. 2014. Influencia del cambio climático en el desarrollo de plagas y enfermedades de cultivos en Sonora. Revista Mexicana de Ciencias Agrícolas 5(10):1913-1921.

[15] Martínez S. 2017. El tiempo, las plagas (animal y/o vegetal) y las plantas. Pronóstico de enfermedades y plagas. Facultad de Ciencias Agrarias y Forestales, Universidad Nacional de la Plata. Buenos Aires, Argentina. 6 p.

[16] Morales-Coronado D, Argentel-Martínez L, Castro-Espinoza L, Gutiérrez-Coronado M, Garibaldi-Chávez J, and Ortiz-Enríquez J. 2019. Global warming is reducing the tillering capacity and grain yield of wheat in Yaqui valley, Mexico. Agronomia Colombiana 37(1):5-11. doi: 10.15446/agron.colomb.v37n1.75736.

[17] Castorena Peña JA, Silva Ávila AE, Domínguez Lugo AJ, y Rodríguez Montelongo DL. 2018. El uso de herramientas tecnológicas de minería de datos en el análisis de datos climatológicos. Revista Iberoamericana de las Ciencias Computacionales e Informática 7(13):1-18. doi: 10.23913/reci.v7i13.75.

[18] Vázquez Zavaleta MA. 2018. Minería de datos para generación de reglas de tendencia de precipitación pluvial en el estado de Morelos. Ingeniería Revista Académica de la Facultad de Ingeniería Universidad Autónoma de Yucatán 22(2): 9-24.

[19] Burbano-Vallejo EL y Moreno E. 2018. Análisis de Conglomerados del Norte del valle del 
cauca. Casoestudio Cartago, Zarzal y la Unión. Ingeniería Industrial 39(1):78-91.

[20] Diaz RA y Mormeneo I. 2003. Zonificación del clima de la región pampeana mediante análisis de conglomerados por consenso. Revista Argentina de Agrometeorología 2(2):125131.

[21] Olaiya F, and Barnabas A. 2012. Application of data mining techniques in weather prediction and climate change studies. International Journal of Information Engineering and Electronic Business 4(1):51-59. doi: 10.5815/ijieeb.2012.01.07.

[22] Gambin D y Pallotta E. 2009. Minería de datos aplicada a cultivos de maíz. Facultad de Ingeniería Universidad de Buenos Aires. Buenos Aires, Argentina. 100 p.

[23] Zamora Villalobos TF. 2018. Aplicación de técnicas de minería de datos para pronósticos del sector agrícola. Facultad de Ingeniería Pontificia Universidad Católica de Valparaíso. Valparaíso, Chile. $30 \mathrm{p}$.

[24] Unal Y, Kindap T, and Karaca M. 2003. Redefining the climate zones of Turkey using cluster analysis. International Journal of Climatology 23(9):1045-1055. doi: 10.1002/joc.910.

[25] Hossein K, Zeynolabedin S, Behnam K, Shaban S, and Sohrab S. 2015. Ecological zoning for wheat production at province scale using geographical information system. Advances in Plants \& Agriculture Research 2(1):15-22. doi: 10.15406/apar.2015.02.00035.

[26] Estrada F, Martínez Arroyo A, Fernandez Equiarte A, Luyando E, and Gay C. 2009. Defining climate zones in México City using multivariate analysis. Atmósfera 22(2):175193.

[27] Molero-Castillo G and Meda-Campaña M. 2011. Climatic regionalization using data mining techniques: A case of study. In: 6th Colombian Computing Congress. doi: 10.1109/COLOMCC.2011.5936325.

[28] Harel D, Fadida H, Alik S, Gantz S, y Shilo K. 2014. El efecto de la temperatura media diaria y la humedad relativa con relación al polen, el cuaje de los frutos y el rendimiento del tomate en cultivos comerciales protegidos. NaanDanJain Irrigation Ltd. Na'an, Israel, 4 p.

[29] Coscollá R. 1980. Incidencia de los factores climatológicos en la evolución de las plagas y enfermedades de las plantas. Boletin de Sanidad Vegetal-Plagas 6(2):123-139.

[30] Moine, J.M. 2013. Metodologías para el descubrimiento de conocimiento en bases de datos: un estudio comparativo. Facultad de Ingeniera, Universidad Nacional de La Plata. Buenos Aires, Argentina. 111p.

[31] Sánchez López A, Cruz-Gutiérrez V, Posada-Zamora MA, Torrijos M-MT, y Osorio Lama MA. 2016. Estudio del análisis de componentes principales en bases de datos de calidad del aire. Research in Computing Science 120:9-19.

[32] SAS Institute Inc. 2019. SAS/STAT 15.1 User's Guide. Cary, New York.

[33] Servicio de Información Agroalimentaria y Pesquera (SIAP). 2017. Anuario Estadístico de la Producción Agrícola. https://nube.siap.gob.mx/cierreagricola/. Accessed on June 20, 2019.

[34] Fovell, RG, and Fovell M-YC. 1993. Climate Zones of the Conterminous United States Defined Using Cluster Analysis. Journal of Climate 6(11):2103-2135. http://dx.doi.org/10.1175/1520-0442(1993)006<2103:CZOTCU>2.0.CO;2. 